\title{
Redescription of the sole species of the enigmatic solifuge genus Dinorhax Simon, 1879 (Solifugae: Melanoblossiidae) in Southeast Asia
}

\author{
Authors: Yamasaki, Takeshi, Henriques, Sérgio, Phung, Luong Thi \\ Hong, and Hoang, Quang Duy
}

Source: The Journal of Arachnology, 46(3) : 498-506

Published By: American Arachnological Society

URL: https://doi.org/10.1636/JoA-S-17-090.1

BioOne Complete (complete.BioOne.org) is a full-text database of 200 subscribed and open-access titles in the biological, ecological, and environmental sciences published by nonprofit societies, associations, museums, institutions, and presses.

Your use of this PDF, the BioOne Complete website, and all posted and associated content indicates your acceptance of BioOne's Terms of Use, available at www.bioone.org/terms-of-use.

Usage of BioOne Complete content is strictly limited to personal, educational, and non - commercial use. Commercial inquiries or rights and permissions requests should be directed to the individual publisher as copyright holder.

BioOne sees sustainable scholarly publishing as an inherently collaborative enterprise connecting authors, nonprofit publishers, academic institutions, research libraries, and research funders in the common goal of maximizing access to critical research. 


\title{
Redescription of the sole species of the enigmatic solifuge genus Dinorhax Simon, 1879 (Solifugae: Melanoblossiidae) in Southeast Asia
}

Takeshi Yamasaki ${ }^{1}$, Sérgio Henriques ${ }^{2}$, Luong Thi Hong Phung ${ }^{3}$ and Quang Duy Hoang ${ }^{4}$ : ${ }^{1}$ Department of Biological Sciences, Tokyo Metropolitan University, Minami-osawa 1-1, Hachioji-shi, Tokyo 192-0397, Japan; E-mail: k0468874@kadai.jp; ${ }^{2}$ University College London, Gower Street, London WC1E 6BT, UK; ${ }^{3}$ Institute of Ecology and Biological Resources, Vietnam Academy of Science and Technology, 18 Hoang Quoc Viet Road, Cau Giay District, Hanoi, Vietnam; ${ }^{4}$ Tay Nguyen University, 567 Le Duan streets, Buon Ma Thuot city, Dak Lak province, Vietnam.

\begin{abstract}
We present the first recorded description of females of the species Dinorhax rostrumpsittaci (Simon, 1877) from solifugae specimens obtained from southern Vietnam. As a result of DNA barcoding using males identified as $D$. rostrumpsittaci and unidentified females, these female specimens made a highly supported cluster with male $D$. rostrumpsittaci. Hereby, we describe the female D. rostrumpsittaci and its natural habitats.
\end{abstract}

Keywords: Dinorhax rostrumpsittaci, camel spiders, Indo-china, southern Vietnam, DNA barcoding

While most solifuges are restricted to arid ecosystems (Harvey 2003), Dinorhax rostrumpsittaci (Simon, 1877) is unusual for its occurrence in tropical Southeast Asia. In addition to D. rostrumpsittaci, a fossil species considered to be closely related to Dinorhax has recently been recorded from Cretaceous Myanmar amber (Dunlop et al. 2015; Bartel et al. 2016). Dinorhax rostrumpsittaci was originally described by Simon (1877) in the genus Rhax Hermann, 1804, possibly on the basis of a single specimen from Gilolo, which is now known as Halmahera, in Indonesia. Simon (1879a) transferred it to the new genus Dinorhax, and mentioned southern Vietnam as an additional location. Subsequently, several arachnologists who examined the Solifugae collection in the Muséum National d'Histoire Naturelle (Paris) noted two male specimens from Cochinchina and Bachieu (Kraepelin 1899, 1901, 1908; Roewer 1932, 1933). Cochinchina was a large region in southern Vietnam during the French colonization period, whereas Bachieu [Ba Chieu] is located in Ho Chi Minh City (Vietnam). Roewer (1941) noted that two male specimens from Nha Trang (Vietnam) are deposited at a museum in Leningrad. In addition, Bird et al. (2015) examined a male from Ba Ria-Vung Tau province and another male from Khanh Hoa province; these specimens are currently deposited at the American Museum of Natural History (New York) and Musée Royal de l'Afrique Central (Tervuren), respectively. Although the males of this species are moderately well characterized, females have not been described.

We gathered information about Solifugae from a natural history group in Vietnam via a social networking service and obtained specimens collected by local collaborators (Fig. 1). Among these specimens, we found two females which we confirmed were conspecific to male specimens identified as $D$. rostrumpsittaci using the mitochondrial barcoding gene cytochrome $c$ oxidase I. Herein, we describe the female $D$. rostrumpsittaci for the first time and provide additional data on males and their natural habitats.

\section{METHODS}

The material examined for the present study is lodged in the Institute of Ecology and Biological Resources, Vietnam
Academy of Science and Technology, Hanoi (IEBR). The specimens were examined using a Nikon SMZ1270 stereoscope. Images were captured using a Cannon D60 digital camera attached to a Nikon SMZ1270, and focal planes of single image series were combined using Helicon focus 4.2.9. In addition, habitus images were captured using an Olympus TG-4 digital camera.

Molecular analysis.-The specimens used in the present study are shown in Table 1. DNA was extracted from the legs of the specimens using the Chelex-TE extraction protocol (Phung et al. 2016). A fragment of approximately $630 \mathrm{bp}$ of the mitochondrial COI region was amplified using the primer set LCO1490/HCO2198 (Folmer et al. 1994). Each PCR contained $5 \mu \mathrm{L}$ of $2 \times$ PCR buffer (TOYOBO), $2 \mu \mathrm{L}$ of dNTPs (final concentration, $0.4 \mathrm{mM}$ ), $0.3 \mu \mathrm{L}$ of $10 \mathrm{pmol} / \mu \mathrm{L}$ forward and reverse primers (final concentration, $0.3 \mu \mathrm{M}$ ), $0.2 \mu \mathrm{L}$ of $1.0 \mathrm{U} / \mu \mathrm{L}$ DNA polymerase KOD FX Neo (TOYOBO KFX-2015), and $0.5 \mu \mathrm{L}$ of DNA template. The final volume of PCR reaction was adjusted to $10 \mu \mathrm{L}$ by DEPC treated water. The PCR thermal regime comprised one cycle of $2 \mathrm{~min}$ at $94^{\circ} \mathrm{C}$ and 5 cycles of $10 \mathrm{~s}$ at $98^{\circ} \mathrm{C}, 30 \mathrm{~s}$ at $45^{\circ} \mathrm{C}$, and $45 \mathrm{~s}$ at $68^{\circ} \mathrm{C} ; 35$ cycles of $10 \mathrm{~s}$ at $98^{\circ} \mathrm{C}, 30 \mathrm{~s}$ at $52^{\circ} \mathrm{C}$, and $45 \mathrm{~s}$ at $68^{\circ} \mathrm{C}$; and a final cycle of $7 \mathrm{~min}$ at $68^{\circ} \mathrm{C}$. The amplified products were incubated at $37^{\circ} \mathrm{C}$ for $30 \mathrm{~min}$ and at $80^{\circ} \mathrm{C}$ for 20 min with an Illustra ${ }^{\mathrm{TM}}$ ExoStar (GE Healthcare, Buckinghamshire, UK) to remove any excess primers and nucleotides. The cycle sequencing reactions were run with an ABI PRISM BigDye Terminator Cycle Sequencing Kit v.3.1 (Applied Biosystems). The sequencing reaction products were purified and concentrated by ethanol precipitation with sodium acetate, and their nucleotide sequences were determined using an automated sequencer (ABI PRISM 3100, Applied Biosystems). The sequences obtained were assembled using ChromasPro 1.7.6 (Technelysium Pty Ltd., Australia). Further, these sequences were aligned using MUSCLE (Edgar 2004) built in MEGA 6.06 (Tamura et al. 2013). The genetic divergence in the K2P model (Kimura 1980) was calculated by the pairwise comparison method. The mitochondrial COI sequences obtained in the present study are deposited in the DNA Data Bank of Japan, and thus will also be available through GenBank. 


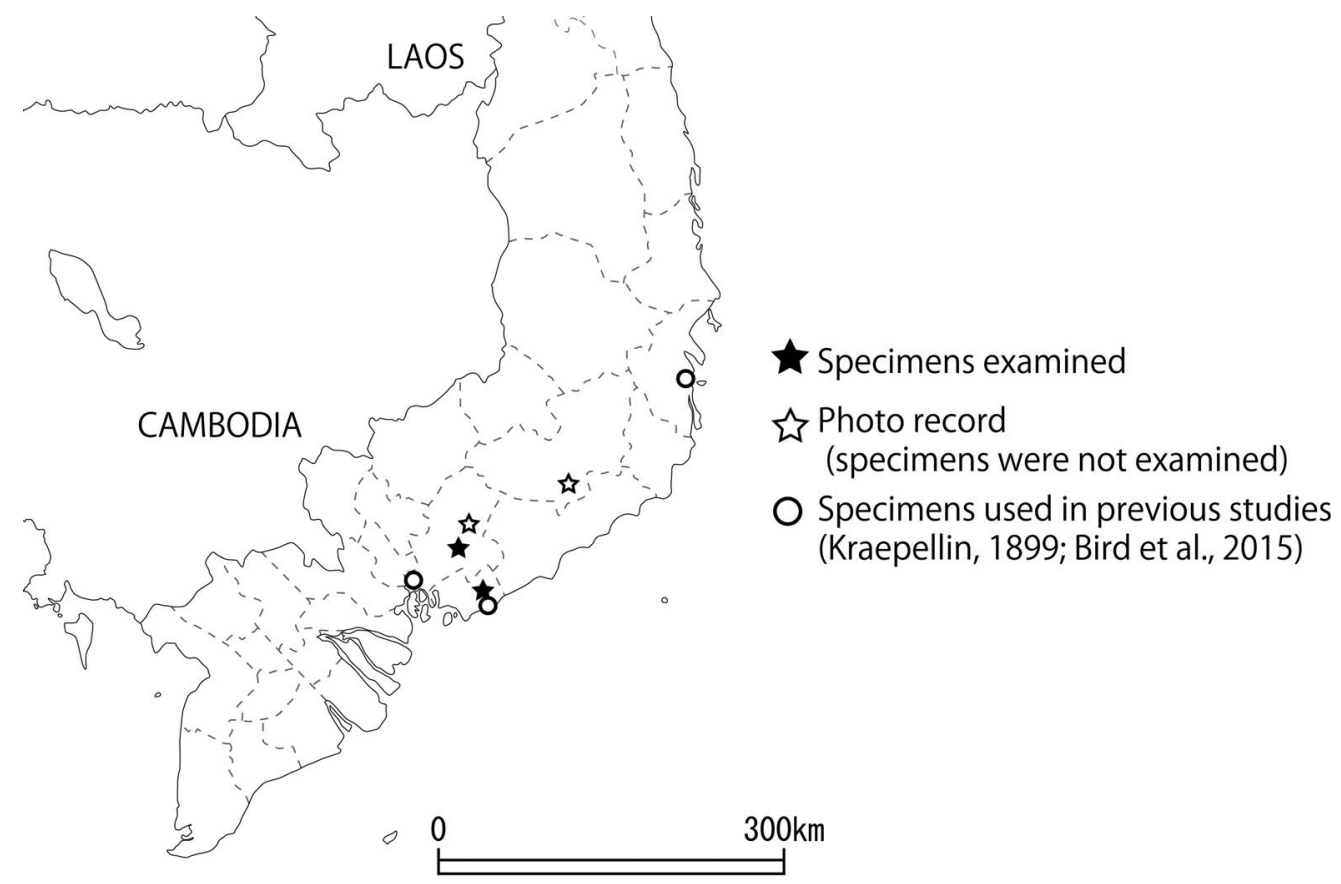

Figure 1.-Distribution of Dinorhax rostrumpsittaci in southern Vietnam. Black stars represent the localities of the specimens used in the present study; white stars represent the localities where local collaborators observed specimens (habitat photos shown in Figs. 30-33); and white circles represent the localities of the specimens recorded by Kraepelin (1899) and Bird et al. (2015).

Morphology description.-All measurements are provided in millimeters. Cheliceral terminology, measurements, and dental formulae follow the descriptions by Bird et al. (2015) and Bird \& Wharton (2015). Abbreviations used in the present study are as follows: FD, distal tooth on fixed finger; FM, medial tooth on the fixed finger; FP, proximal tooth on the fixed finger; MM, medial tooth on the movable finger; MP, proximal tooth on the movable finger; $\mathrm{PF}$, profondal tooth; RF, retrofondal tooth; MPL, prolateral tooth on the movable finger; MRLC, retrolateral carina on movable finger.

\section{RESULTS}

In this study, we obtained approximately $630 \mathrm{bp}$ fragment of the mitochondrial COI fragment from each specimen. The genetic divergence among the specimens is shown in Table 2. Notably, there was no genetic divergence among two unidentified females (SL05, SL06) and two males (SL03, SL04) identified as D. rostrumpsittaci, strongly suggesting that the two females are conspecific with $D$. rostrumpsittaci. For our discussion on the high divergence between one male (SL02) and the other specimens, please see Remarks of the species below.

\section{TAXONOMY}

Family Melanoblossiidae Roewer, 1933

Subfamily Dinorhaxinae Roewer, 1933

Genus Dinorhax Simon, 1879

Dinorhax Simon 1879a: 125; Simon 1879b: 78; Kraepelin 1901: 41; Roewer 1933: 341.

Remarks.- The sole species of this genus, D. rostrumpsitta$c i$, was originally described as a member of the genus Rhax,

Table 1.- Specimens used in the present study.

\begin{tabular}{|c|c|c|c|c|}
\hline Species & Sex & Code & Locality & $\begin{array}{c}\text { Accession } \\
\text { No. }\end{array}$ \\
\hline \multirow[t]{4}{*}{ D. rostrumpsittaci } & Male & SL02 & Long Khanh, Dong Nai province & LC328806 \\
\hline & Male & SL04 & Xuyen Moc district, Ba Ria Vung Tau province & LC328808 \\
\hline & Female & SL05 & Xuyen Moc district, Ba Ria Vung Tau province & LC328809 \\
\hline & Female & SL06 & Xuyen Moc district, Ba Ria Vung Tau province & LC328810 \\
\hline
\end{tabular}




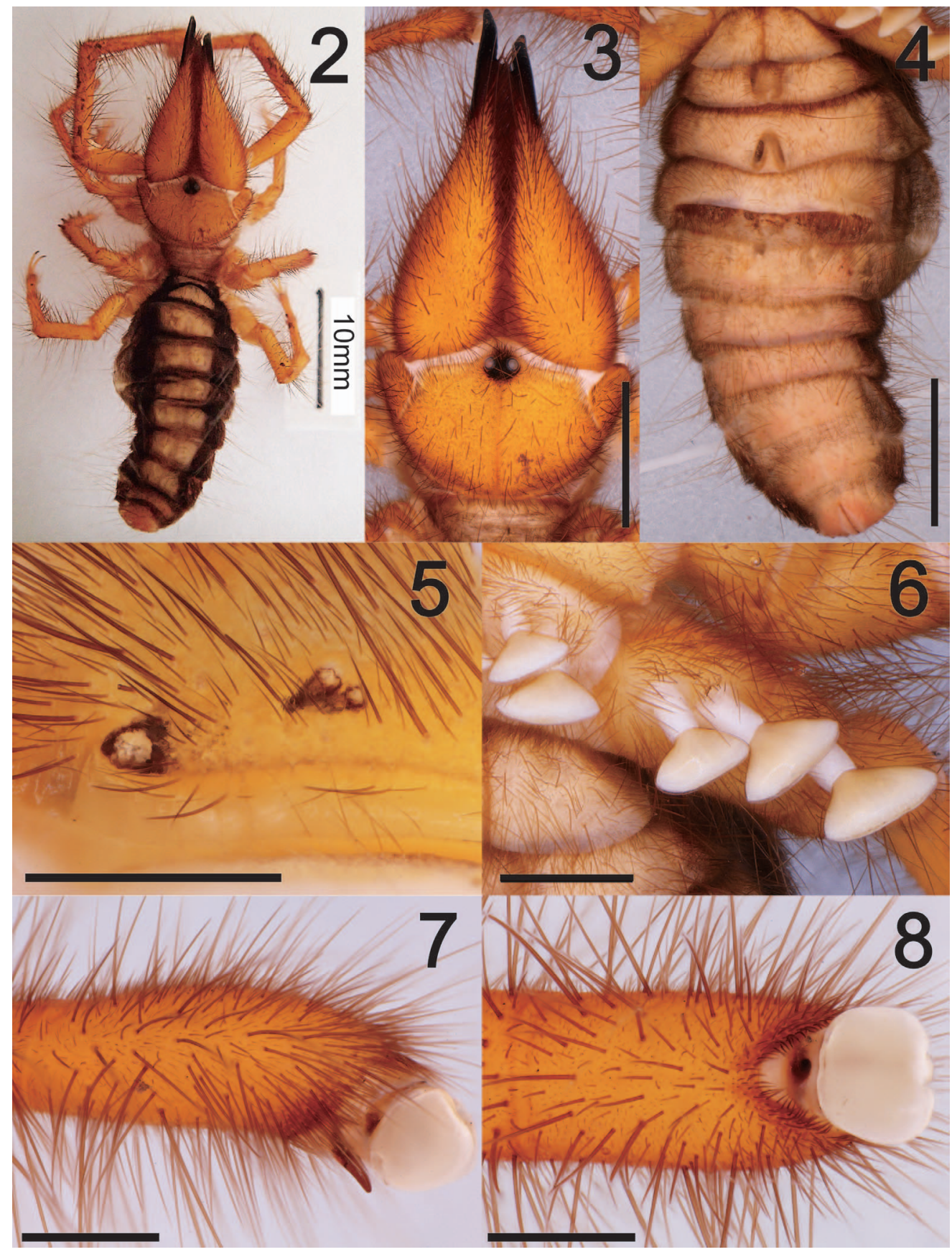

Figures 2-8.-Dinorhax rostrumpsittaci, male (IEBR_SL03): 2. Habitus, dorsal view. 3. Prosoma, dorsal view. 4. Abdomen, ventral view. 5. Eyespots, lateral view. 6. Malleoli, ventral view. 7. Left pedipalp, prolateral view. 8 Left pedipalp, ventral view. Scale bars $=10 \mathrm{~mm}($ Fig. 2$) ; 5$ mm (Figs. 3, 4); 1 mm (Figs. 5, 7, 8); 2 mm (Fig. 6).

Table 2.-Pairwise distances in K2P model are shown below the diagonal. Standard errors are shown above the diagonal.

\begin{tabular}{llllll}
\hline Specimen & SL02 & SL03 & SL04 & SL05 & SL06 \\
\hline SL02 & & 0.009 & 0.009 & 0.009 & 0.009 \\
SL03 & 0.047 & & 0.000 & 0.000 & 0.000 \\
SL04 & 0.047 & 0.000 & & 0.000 & 0.000 \\
SL05 & 0.047 & 0.000 & 0.000 & & 0.000 \\
SL06 & 0.047 & 0.000 & 0.000 & 0.000 & \\
\hline
\end{tabular}




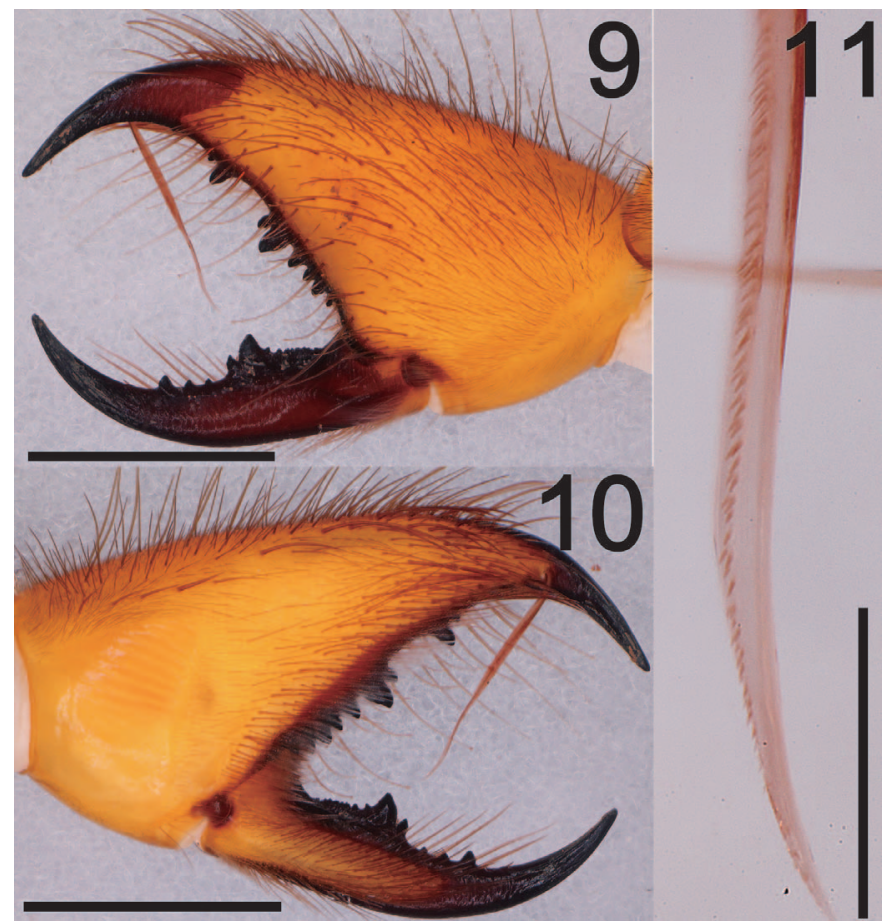

Figures 9-11.-Dinorhax rostrumpsittaci, male (IEBR_SL03): 9. Left chelicera, retrolateral view. 10. Left chelicera, prolateral view. 11. Flagellum. Scale bars $=5 \mathrm{~mm}$ (Figs. 9, 10); $1 \mathrm{~mm}$ (Fig. 11).

but was transferred to the monotypic genus Dinorhax by Simon (1879a) due to the absence of the tarsal claw on tibia I. Currently, this genus is placed in the family Melanoblossiidae (Roewer 1933). However, Bird et al. (2015) suggest that "the inclusion of Dinorhax in Melanoblossiidae probably renders this family polyphyletic."

\section{Dinorhax rostrumpsittaci (Simon, 1877)}

(Figs. 2-27)

Rhax rostrumpsittaci Simon, 1877: 225 (as Rhax rostrumpsittaci).

Dinorhax rostrumpsittaci (Simon): Simon, 1879a: 126, fig. 16 (as Dinorhax rostrum-psittaci); Simon, 1879b: 78 (as Dinorhax rostrum-psittaci); Kraepelin, 1899: 377 (as Dinorhax rostrum psittaci); Kraepelin, 1901: 41, fig. 12 (as Dinorhax rostrum-psittaci); Kraepelin, 1908: fig. 56; Roewer, 1932: fig. 142 (as Dinorhax rostrumpsittaci); Roewer, 1933: 341, fig. 248 (as Dinorhax rostrum psittaci); Roewer, 1941: 123 (as Dinorhax rostrum psittaci); Harvey, 2003: 287; Bird et al., 2015: 188, pls. 23d, 25A, 30E, 31C, 41A, 46B, 56A-B, 57A-B.

Material examined.-VIETNAM: Dong Nai province: 1 o (IEBR_SL02), Long Khanh district $\left(10^{\circ} 56^{\prime} 41.4^{\prime \prime} \mathrm{N}\right.$ $\left.107^{\circ} 13^{\prime}-14.9^{\prime \prime} \mathrm{E}\right), 24$ May 2017, Phung Thi Hong Luong leg. (IBER); Ba Ria Vung Tau province: 2 o (IEBR_SL03,

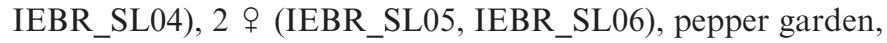
Xuyen Moc district (10 $\left.42^{\prime} 21.1^{\prime \prime} \mathrm{N} 107^{\circ} 30^{\prime} 56.7^{\prime \prime} \mathrm{E}\right)$, April 2017, Phan Quoc Anh leg. (IBER).
Diagnosis.-Dinorhax rostrumpsittaci is distinguishable from other species by having two or three eyespots on each anterolateral propeltidium lobe, a slit-like anus on the venter of terminal segment of abdomen, three dorsal spiniform setae on metatarsus II and III, and one-segmented tarsi II, II, and IV. In males, the cheliceral fixed finger possesses one sessileform flagellum extending ventrally.

Description.-Measurements $(30 / 2 \%$; means in parentheses): Propeltidium length 60.0-68.2 (63.7)/50.0-55.0 (52.5); width 90.0-112.6 (101.6)/89.0 (89.0). Ocular tubercle length $1.00-1.16(1.05) / 0.73-0.75(0.74)$; width $1.36-1.40(1.38) / 1.03-$ 1.13 (1.08). Ocellus diameter $0.50-0.63(0.59) / 0.40-0.43(0.41)$. Chelicera length 134.9-153.9 (144.0)/109.5-111.1 (110.3); width 38.0-50.7 (43.1)/35.0-37.0 (36.0); height 62.0-77.7 (69.9)/56.0 (56.0). Pedipalp 260.3-287.2 (272.6)/176.9 (176.9); leg I 195.0-217.1 (206.1)/147.0 (147.0); leg IV 222.2-262.0 (241.5)/164.0-168.0 (166.0).

Male (Figs. 2-11, 24): Propeltidium much wider than long (Figs. 2, 3); median eyes separated by less than one diameter (Fig. 3); two or three small eyespots located near lateral margin of each anterolateral propeltidium lobe (Fig. 5). Abdomen tapering posteriorly, with ventral anus (Fig. 4). Dental formulation of fixed finger: FD-(1)-FM-(1)-FP (3RF or $4 \mathrm{RF})(4 \mathrm{PF}$ or $5 \mathrm{PF})$; FD minute (Figs. 9, 10, 24). Dental formulation of movable finger: MM-(3)-MP with MRLC; MP accompanying serrated teeth posteriorly (Figs. 9, 10, 24). Flagellum sessile form, directly projecting from basal part of terminal tooth in prolateral view (Fig. 10); shaft bearing longitudinal row of small denticles (Fig. 11). Pedipalp with one apical claw on tarsus (Figs. 7, 8). Leg I without claw. Legs II \& III with two apical claws on each tarsus; one dorsal spiniform seta on apex of each postfemur; three dorsal spiniform setae on each metatarsus. Leg IV with two apical claws on tarsus; dorsum without spines; two malleoli on venter of coxa, two on trochanter 1 and one on trochanter 2 (Fig. 6).

Coloration and setation in alcohol preservation (Figs. 2-4). Propeltidium yellowish brown, densely covered with short black setae and sparsely with long black setae. Abdomen densely covered with dark grey setae dorsally, except for cream abdominal sclerites, and ventrally cream. Chelicera yellowish brown, covered with long brownish setae; each terminal tooth of fixed finger and movable finger black, and prolateral margin of fixed finger dentition densely fringed with plumose setae. Pedipalp and legs yellowish brown, covered with brownish setae.

Male variation: Three males were examined for variation. Notably, the number of eyespots and RF in males varies among specimens. Eyespots: Male SL02 has two eyespots on both lateral sides; males SL03 and SL04 have three eyespots on the left side but two on the right side. RF: Males SL02 and SL04 have three RFs, whereas male SL03 has four RFs. The FD is minute among SL02, SL03, and SL04. The sharpness of serration behind MP varies and is relatively blunt in SL02, but it is sharp in SL03 and SL04.

Female (Figs. 12-23, 25-28): Propeltidium almost same as in male (Figs. 12, 13); three small eyespots located at near lateral margin of each anterolateral propeltidium lobe (Fig. 15). Dental formulation of fixed finger: FD-(1)-FM-(1)-FP 


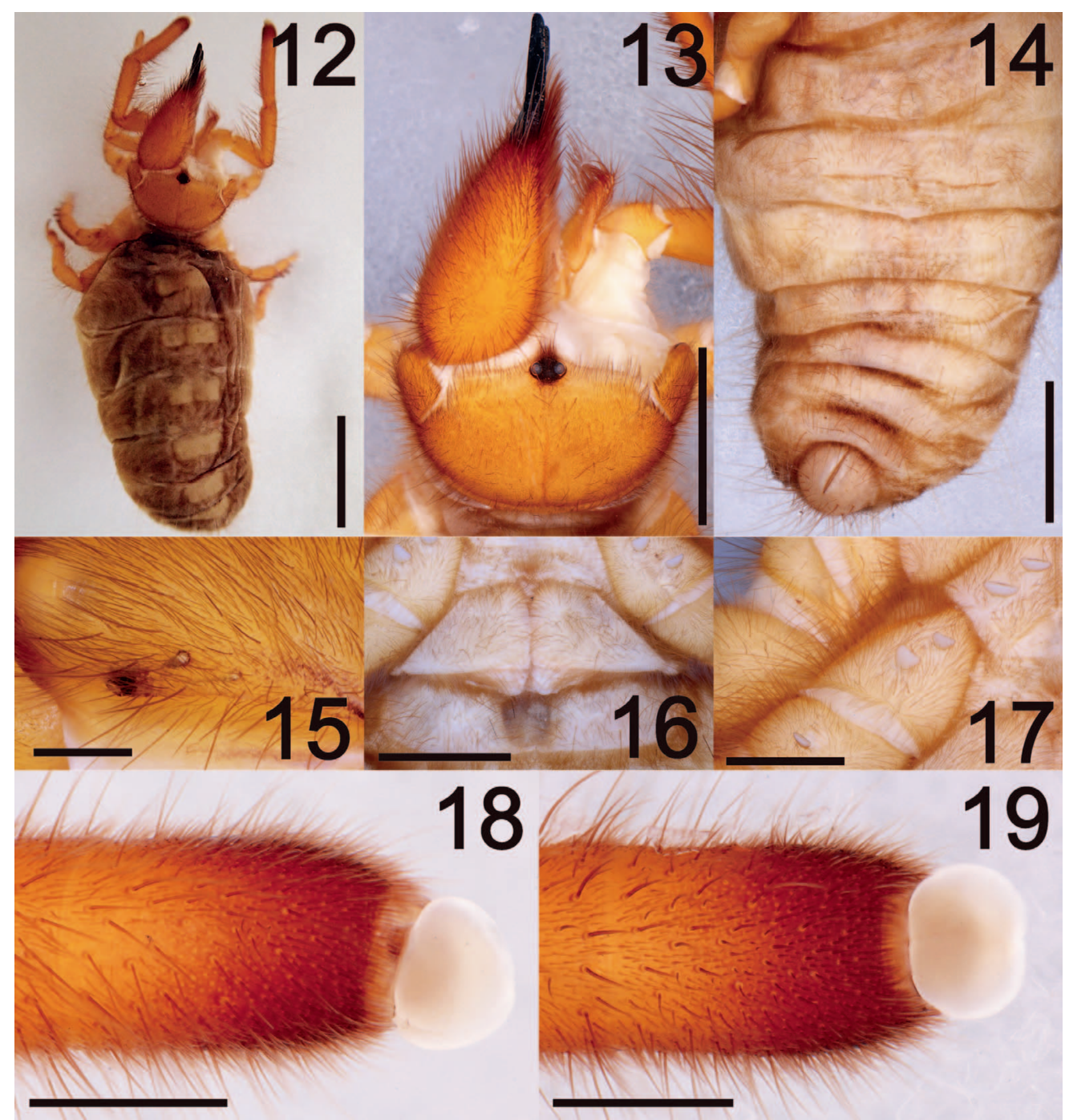

Figures 12-19.-Dinorhax rostrumpsittaci, female (SL05): 12. Habitus, dorsal view. 13. Prosoma, dorsal view. 14. Abdomen, ventral view. 15. Eyespots, lateral view. 16. Genital operculum, ventral view. 17. Malleoli, ventral view. 18. Pedipalp, prolateral view. 19. Pedipalp, ventral view. Scale bars. $10 \mathrm{~mm}$ (Fig. 12); $5 \mathrm{~mm}$ (Figs. 13, 14); $1 \mathrm{~mm}$ (Fig. 15); $2 \mathrm{~mm}$ (Figs. 16, 17); $1 \mathrm{~mm}$ (Figs. 18, 19).

$(3 \mathrm{RF})(3 \mathrm{PF})$, with one or two small teeth located between RF and PF teeth rows (Figs. 20-23, 25, 27). Dental formulation of movable finger: MM-(3)-MP, with 1 MPL (Figs. 20-23, 26, 28). Abdomen almost as in male (Fig. 14); genital operculum shown in Figure 16. Pedipalp without tarsal claw (Figs. 18, 19). Leg spines and tarsal claws almost same as in male. Malleoli small (Fig. 17).

Coloration and setation almost same as in male (Figs. 1214).

Female variation: Two females were examined for variation. Female SL05 has one tooth between the RF and PF teeth rows, whereas SL06 has two small teeth. The size of MM occasionally varies between SL05 and SL06 (Figs. 20, 21, 26 vs. Figs. 22, 23, 28).

Distribution.-Dinorhax rostrumpsittaci has been recorded from Halmahera, Indonesia (type locality) and Khanh Hoa,
Lam Dong, Dong Nai, and Ba Ria-Vung Tau provinces in southern Vietnam. Although Simon (1877) clearly stated the type locality as Iles Moluques: Gilolo [nowadays Moluccas: Halmahera (or Jilolo, Gilolo)] in the original description, all subsequent specimens are from southern Vietnam (Fig. 1), and there are no recorded specimens from Indonesia. Thus, Roewer (1933, 1941) suggested that the record from Halmahera is suspicious, and there is a possibility that the type specimen was somehow mislabeled. However, terrestrial biodiversity inventories in the Malay Archipelago are insufficient to conclude that solifuges do not occur in the Moluccas.

Habitats. - The specimens included in the present study were collected in artificial forest environments such as a pepper garden (Fig. 29). According to the collectors, the specimens were walking on the ground in the daytime after 


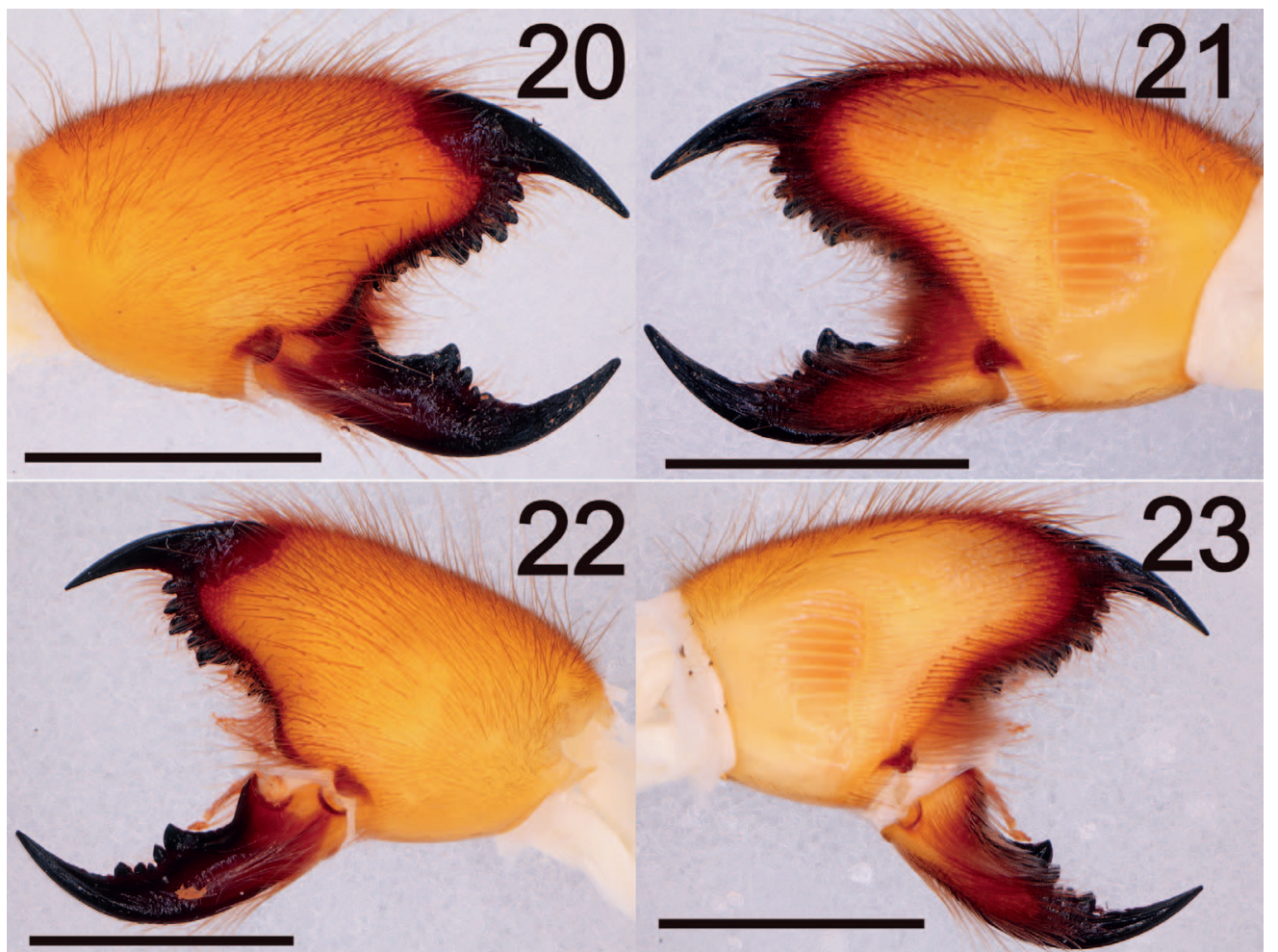

Figures 20-23.-Dinorhax rostrumpsittaci, chelicerae, female (SL05, SL06): 20. Right chelicera (SL05), retrolateral view. 21. same (SL05), prolateral view. 22. Left chelicera (SL06), retrolateral view. 23. same (SL06), prolateral view. Scale bars $=5 \mathrm{~mm}$.

rain during the rainy season (May-September in southern Vietnam). In addition, the species has been found in a teak plantation $\left(11^{\circ} 15^{\prime} 01.7^{\prime \prime} \mathrm{N}, 107^{\circ} 24^{\prime} 19.2^{\prime \prime} \mathrm{E}\right)$ in Dong Nai province (Figs. 1, 30, 31) and a roadside in a montane area $\left(11^{\circ} 19^{\prime} 05.2^{\prime \prime} \mathrm{N}, 108^{\circ} 05^{\prime} 28.7^{\prime \prime} \mathrm{E}\right)$ in Lam Dong province (Figs. 1, $32,33)$. These habitats indicate that D. rostrumpsittaci may prefer relatively open environments rather than primary forests, although surveys in forest preserves are needed to establish whether this is correct.

Remarks. - The male/female combination was confirmed by DNA barcoding (Table 2), and not unexpected as they were collected from the same location and share various diagnostic features of the genus. Although four specimens (SL03-SL06) collected in the same habitat in Xuyen Moc showed no genetic divergence among them, a male (SL02) specimen collected from Long Khanh has a genetic divergence of $4.70 \% \pm 0.90 \%$ from the former specimens in the K2P model (Table 2), without distinct morphological differences. In a study by Maddahi et al. (2016), the average K2P genetic distance varied from $0 \%$ to $7.92 \%$ within the solifuge species Galeodes caspius (Birula, 1890). Therefore, we considered the relatively high divergence value between SL02 and other specimens as merely intraspecific divergence. Although we examined a limited number of specimens, the high mitochondrial divergence between the male from Long Khanh and the others from Xuyen Moc suggests low dispersal ability of $D$. rostrumpsittaci. The fossorial habits and high genetic divergence among the Vietnamese popula- tions of D. rostrumpsittaci imply low dispersal ability and it may be possible in the future to use this species to examine the geographical factors affecting the present distribution of this species.

Although Dinorhax was placed in the family Melanoblossiidae by Roewer (1933), Wharton (1981) doubted its placement and indicated that the insertion point of the flagellum in Dinorhax resembles that in Karschiidae. Bird et al. (2015) noted that Dinorhax resembles Rhagodidae and Hexisopodidae in terms of cheliceral morphology, Eremobatidae in terms of the dentition on the chelicera, and the genus Karschia Walter, 1889 (Karschiidae) in terms of flagellum morphology. As all other melanoblossiids occur in southern Africa (Harvey 2003), the presence of Dinorhax in southeast Asia represents a remarkable disjunct distribution. However, as previously mentioned, the monophyly of Melanoblossiidae has been considered uncertain, and the reevaluation of the morphological characteristics of Dinorhax and further molecular analysis of several gene markers are necessary to conclude the appropriate classification of Dinorhax.

Dunlop et al. (2015) draws several hypotheses regarding a potential ancestor of southeast Asian Solifugae on the basis of a Burmese amber specimen, although their discussion relies on an assumption that the amber specimen is closely related to $D$. rostrumpsittaci. Based on the current classification with $D$. rostrumpsittaci as a member of the Melanoblossiidae, some hypotheses by Dunlop et al. (2015) pursue the ancestor of 


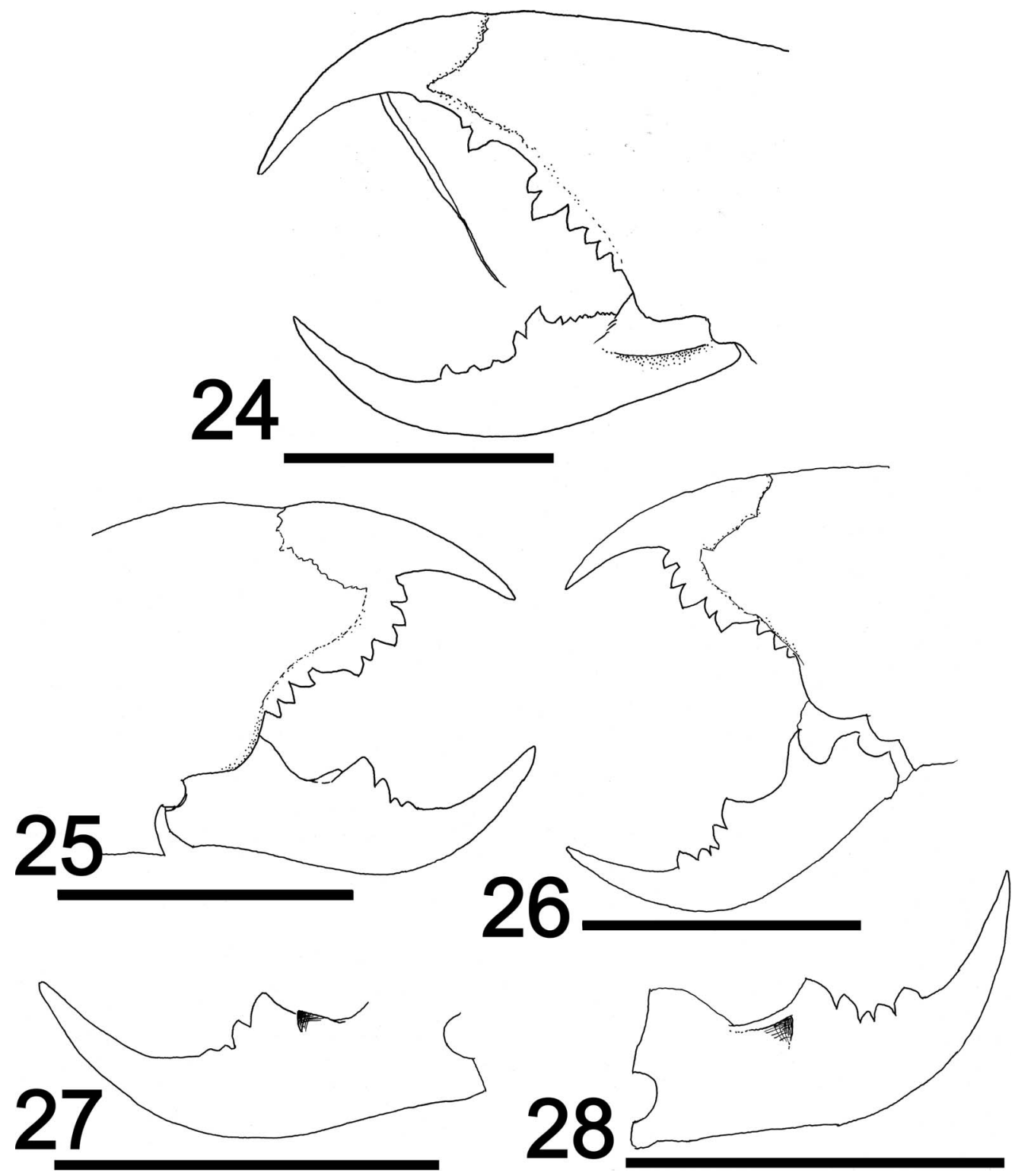

Figures 24-28.-Dinorhax rostrumpsittaci, chelicerae: 24. Left chelicera (SL03), retrolateral view. 25. Right chelicera (SL05), retrolateral view. 26. Left chelicera (SL06), retrolateral view. 27. Movable finger (SL05), right chelicera, prolateral view. 28. Movable finger (SL06), left chelicera, prolateral view. Scale bars $=5 \mathrm{~mm}$. 


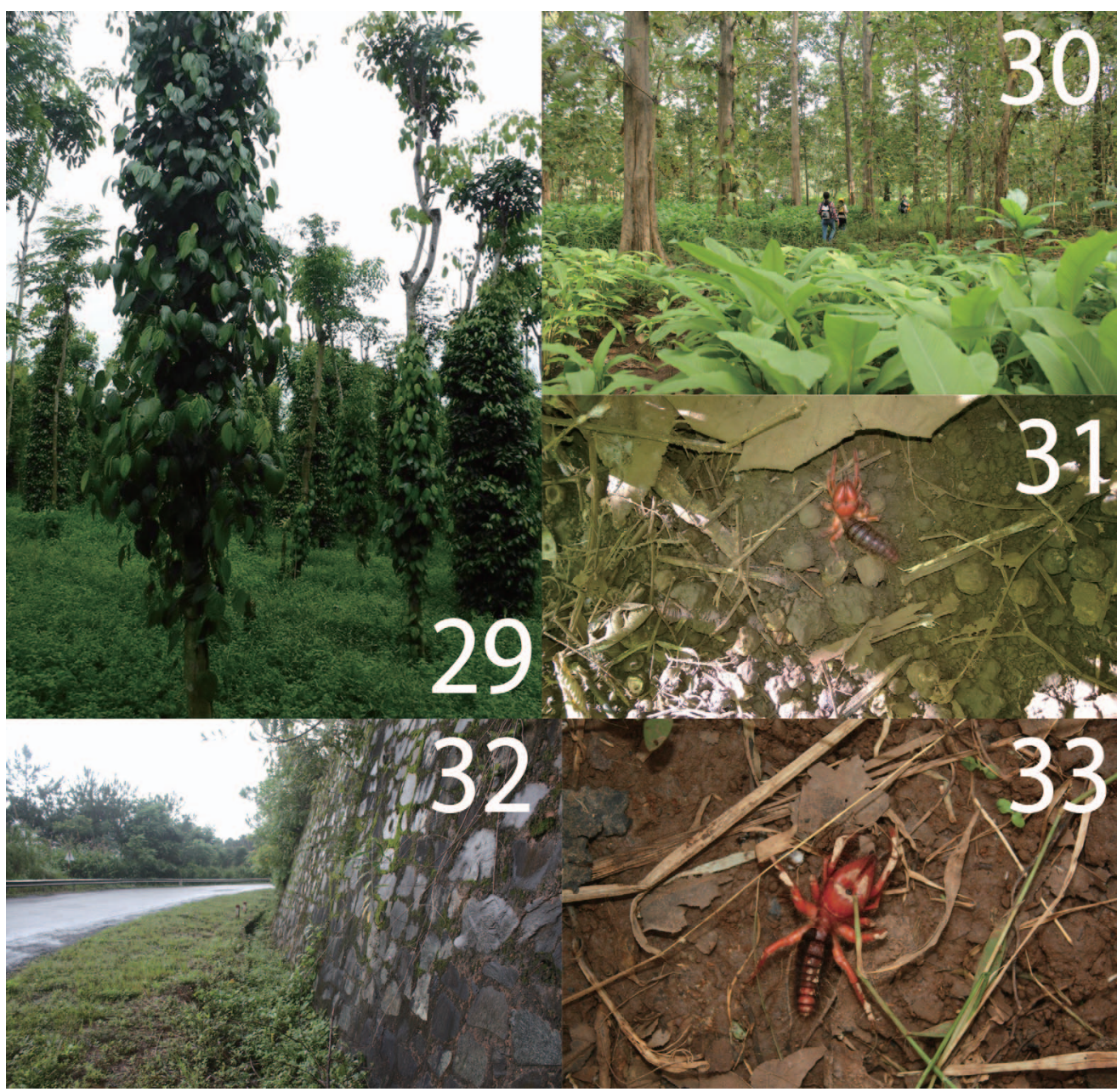

Figures 29-33.- Habitats of Dinorhax rostrumpsittaci. 29. Pepper garden, Xuyen Moc district, Ba Ria Vung Tau province; specimens SL03-06 were collected here. 30. Teak plantation, Dong Nai province (the locality is indicated in Fig. 1 as a white star). A local collaborator observed a $D$. rostrumpsittaci walking across the floor. 31. D. rostrumpsittaci, same locality. 32. Di Linh district, Lam Dong province. One of the authors observed a D. rostrumpsittaci walking on the side of the road (the locality is indicated in Fig. 1 as a white star). 33. D. rostrumpsittaci, same locality. Photo credits: Mr. Phan Quoc Anh (Fig. 29); Mr. Truong Ba Vuong (Figs. 30, 31); and Mr. Quang Duy Hoang (Figs. 32, 33).

African Melanoblossiidae. However, the monophyly of Melanoblossiidae is still controversial considering morphology and molecular phylogeny.

\section{ACKNOWLEDGMENTS}

Our study was conducted in accordance with the Memorandum of Understanding signed between the Institute of Ecology and Biological Resources, Vietnam Academy of Science and Technology and Graduate School of Science and Engineering, Tokyo Metropolitan University (TMU). We would like to thank Mr. Phan Quoc Anh and Mr. Truong Ba Vuong for offering valuable information about Vietnamese Solifugae, to Prof. Noriaki Murakami (TMU) and Assoc. Prof. Katsuyuki Eguchi (TMU) for offering laboratory facilities, and to two anonymous referees for their helpful comments for the manuscript.

\section{LITERATURE CITED}

Bartel, C., J.A. Dunlop \& T.L. Bird. 2016. The second camel spider (Arachnida, Solifugae) from Burmese Amber. Arachnology 17:161-164.

Bird, T.L. \& R.A. Wharton. 2015. Description of a new solifuge Melanoblossia ansie sp. n. (Solifugae, Melanoblossiidae) with notes on the setiform flagellar complex of Melanoblossiinae Roewer, 1933. African Invertebrates 56:515-525.

Bird, T.L., R.A. Wharton \& L. Prendini. 2015. Cheliceral morphology in Solifugae (Aranida): primary homology, terminology, and character survey. Bulletin of the American Museum of Natural History 394:1-355.

Dunlop, J.A., T.L. Bird, J.O. Brookhart \& G. Bechly. 2015. A camel spider from Cretaceous Burmese amber. Cretaceous Research $56: 265-273$.

Edgar, R.C. 2004. MUSCLE: multiple sequence alignment with high accuracy and high throughput. Nucleic Acids Research 32:17921797.

Folmer, O., M. Black, W. Hoseh, R. Luts \& R. Vrijenhoekz. 1994. 
DNA primers for amplification of mitochondrial cytochrome $\mathrm{c}$ oxidase subunit I from diverse metazoan invertebrates. Molecular Marine Biology and Biotechnology 3:294-299.

Harvey, M.S. 2003. Catalogue of the Smaller Arachnid Orders of the World: Amblypygi, Uropygi, Schizomida, Palpigradi, Ricinulei and Solifugae. CSIRO Publishing, Melbourne.

Kimura, M. 1980. A simple method for estimating evolutionary rate of base substitutions through comparative studies of nucleotide sequences. Journal of Molecular Evolution 16:111-120.

Kraepelin, K. 1899. Catalogue des Solifuges (?) des collections du Muséum d'histoire Naturelle de Paris. Bulletin du Muséum National d'Histoire Naturelle, Paris 5:376-378.

Kraepelin, K. 1901. Palpigradi und Solifugae. Tierreich 12:i-xi, 1159.

Kraepelin, K. 1908. Die sekundären Geschlechtscharaktere der Skorpione, Pedipalpen und Solifugen. Mitteilungen aus dem Naturhistorischen Museum in Hamburg 25:182-225.

Maddahi, H., M. Khazanehdari, M. Aliabadian, H.G. Kami, A Mirshamsi \& O. Mirshamsi. 2016. Mitochondrial DNA phylogeny of camel spiders (Arachnida: Solifugae) from Iran. Mitochondrial DNA Part A 28:909-919.

Phung, T.H.L., T. Yamasaki \& K. Eguchi. 2016. Conspecificity of Phintella aequipeiformis Zabka, 1985 and P. lucai Zabka, 1985 (Araneae: Salticidae) confirmed by DNA barcoding. Revue Suisse de Zoologie 123:283-290.

Roewer, C.F. 1932. Solifugae, Palpigradi. Vol. 5(IV)(4)(1). Pp. 1-160.
In Klassen und Ordnungen des Tierreichs. 5: Arthropoda. IV: Arachnoidea (Bronn, H.G. Ed.), Akademische Verlagsgesellschaft M.B.H., Leipzig.

Roewer, C.F. 1933. Solifugae, Palpigradi. Vol. 5(IV)(4)(2-3). Pp. 161-480. In Klassen und Ordnungen des Tierreichs. 5: Arthropoda. IV: Arachnoidea (Bronn, H.G. Ed.), Akademische Verlagsgesellschaft M.B.H., Leipzig.

Roewer, C.F. 1941. Solifugen 1934-1940. Veröffentlichungen des Deutschen Kolonial Ubersee-Museums, Bremen 3:97-192.

Simon, E. 1877. Arachnides nouveaux ou peu connus. Annales de la Société Entomologique de France (5) 7:225-242.

Simon, E. 1879a. Essai d'une classification des Galéodes, remarques synonymiques et description d'espèces nouvelles ou mal connues. Annales de la Société Entomologique de France (5) 9:93-154.

Simon, E. 1879b. Les Ordres des Chernetes, Scorpiones et Opiliones. Vol. 7. Pp. 1-332. In Les Arachnides de France, Librairie Encyclopédique de Roret, Paris.

Tamura, K., G. Stecher, D. Peterson, A. Filipski \& S. Kumar. 2013. MEGA6: Molecular evolutionary genetics analysis version 6.0. Molecular Biology and Evolution 30:2725-2729.

Wharton, R.A. 1981. Namibian Solifugae (Arachnida). Cimbebasia Memoir 5:1-87.

Manuscript received 24 October 2017, revised 1 June 2018. 